\title{
Under what institutional conditions do business groups enhance innovation performance?
}

\begin{abstract}
This study examines the institutional mechanisms through which business groups impact innovation in emerging markets. Rather than merely viewing groups as the result of a weak institutional environment, this study proposes that there are complementary elements between groups and institutions, enabling groups to benefit from interactions with their institutional environment. Evidence from a large sample of Chinese firms indicates that the effects of groups on innovation are pronounced when the group is affiliated to a higher level government agency and when the level of region-specific marketization is higher. The findings point to the context-dependent nature of the innovation and the existence of both substitution and complementary effects between business groups and institutions.
\end{abstract}

Key words: business group, innovation, institutions, government, state ownership, China 


\section{Introduction}

Institutional theory suggests that innovation depends on the interaction between the firm and its external environment (Mahmood, Chung, \& Mitchell, 2012). Emerging markets, such as China, have less developed institutions, making the role of business groups crucial in addressing institutional voids - defined as the paucity of the specialized intermediaries needed to consummate transactions (Ricart, Enright, Ghemawat, Hart, \& Khanna, 2004). As such, scholars often argue that business groups - legally independent firms bound together in formal and informal ways (Granovetter, 1995) - may facilitate innovation. Yet, although groups may compensate for the lack of sufficiently developed institutions (Khanna \& Yafeh, 2007), knowledge of how institutions influence innovation in business groups in emerging markets remains rather limited.

Prior studies on the relationship between group affiliation and innovation have produced mixed findings, ranging from a positive effect (e.g., Amsden \& Hikino, 1994) to a negative effect (Seru, 2007) and an inverted-U relationship (Mahmood \& Mitchell, 2004). Therefore, it remains unclear why some groups benefit from innovation, but others do not (Chang, Chung, \& Mahmood, 2006). The mixed empirical results suggest that the relationship between group affiliation and innovation varies in different contexts. The current study develops a contingency model to examine the institutional conditions under which group affiliation impacts innovation of emerging market enterprises (EMEs). The paper contributes to the literature in two ways.

First, while prior research acknowledges that connections to governments help firms gain competitive advantages, little research has examined the role of different types of government involvement (Wang, Hong, Kafouros, \& Wright, 2012). The current study addresses this gap by considering how the value of group affiliation is influenced by the level of state ownership of the group, and by examining the idiosyncratic manner in which these 
groups are affiliated to government. The distinction between state ownership and government affiliation is important because, as prior research has shown, it reflects that firms exploit political advantages either by creating ties with government (government affiliation) or by incorporating government agents in their internal hierarchy (state ownership) (Boddewyn \& Brewer, 1994; Wang et al., 2012). It also recognizes that a firm's network is composed of different types of relationships (Lin, 2001) that can facilitate different advantages, create different pressures and impact innovation differently.

Second, although the innovation literature often assumes institutional homogeneity within a given nation, in reality there is significant heterogeneity in the marketization level of different sub-national regions. Hence, rather than assuming that groups have to deal with the same institutional voids in each region, the study examines how the relationship between organizations and institutions varies across different institutional contexts. This conceptualization advances the premise that the value of group affiliation depends on location-specific institutional characteristics, namely, the level of market development in each region.

\section{Theoretical framework and hypotheses}

\subsection{Business groups, innovation and institutional environment}

Affiliation with a group may improve innovation. Transaction cost analyses suggest that groups can respond to market failures and imperfections, and reduce the transaction costs associated with innovation by internalizing processes in the group (Khanna \& Palepu, 1997). Similarly, from a resource-based point of view (Barney, 1991), groups provide not only an internal market for factors such as capital and labor for innovative activities but also a platform for sharing resources (Chang \& Hong, 2000). An internal labor market, for example, can help a firm counter the rigidities and variations of the external labor market (Mahmood \& 
Mitchell, 2004), enabling groups to allocate available scientific talent to the most suitable projects (Khanna \& Palepu, 1997).

In line with the above view, political scientists suggest that government influences the development of groups, particularly in emerging markets (Evans, 1979). Hence, a group's political capital acquired through its political ties may enhance its innovative activities. On the other hand, groups can use their economic power to shape a pro-innovation environment by influencing regulatory institutions. Furthermore, theory on organizational learning (Zander \& Kogut, 1995) suggests that groups facilitate organizational learning by bringing together and transferring diverse knowledge across their affiliates. Knowledge sharing compensates for weaknesses in external technology markets (Chang, Chung, \& Mahmood, 2006), improving affiliates' ability to create unique technological combinations (Kafouros, Buckley \& Clegg, 2012).

However, groups may also hinder innovation. The internal market within groups may be inefficient due to agency problems arising when affiliates seek to maximize their budget allocation whereas the headquarters seeks to maximize the performance of the group as a whole (Seru, 2007). This agency problem can lead to misallocation of resources and crosssubsidization of unprofitable ventures by the profitable ones (George \& Kabir, 2012). Groups will respond less efficiently to market failures and even hamper innovation when headquarters allocate resources in a way that leads to "tunneling" of assets from smaller to large members (La Porta, Lopez-de-Silanes, Shleifer, \& Vishny, 2000). Similarly, industrial organization thinking suggests that as groups have significant market power, they block new entrants, create barriers to knowledge inflows from new businesses and therefore limit the diversity of new ideas (Mahmood \& Mitchell, 2004).

Institutional theory reinforces the above predictions. Isomorphic pressures, such as coercive, normative and mimetic forces (Scott, 1995), influence firms' innovative activities in 
two ways. First, innovation strategies, structures and processes must be congruent with institutional demands. The coercive forces coming from governments can exert pressures through laws, regulations and policies. Because groups in emerging economies are created not only by market forces but also by governments as an instrument to implement market reforms (Yiu, Bruton, \& Lu, 2005), they are more likely to be influenced by such pressures than independent firms. For example, normative expectations influence the willingness of group managers to innovate because fulfilling government goals such as technological catch up can accelerate their career. Also, due to mimetic isomorphic pressures, firms facing uncertainty are likely to imitate others that have gained legitimacy by innovating (DiMaggio \& Powell, 1983).

Second, institutions influence the availability and cost of innovation inputs as well as the protection of innovation outputs. For example, institutions governing the employment of scientists and engineers influence the availability and cost of labour, and thus the decisions of groups about hiring labour for innovation. Because capital markets, intermediaries and contract enforcement laws are not well developed in emerging markets, EMEs often need to form ties with government to obtain critical resources and secure favorable treatment that circumvents institutional voids. Furthermore, the intellectual property rights (IPR) regime including patent and copyright laws is a crucial part of a country's institutional infrastructure for innovation. It affects not only the incentives to innovate but also the extent to which firms can appropriate value from their innovations. Because the institutional environment in emerging markets features a weak IPR regime, it often discourages innovation.

\subsection{The role of government involvement}

Government involvement can manifest itself in two conceptually and empirically different forms: government affiliation and state ownership. The former captures a firm's relationship with government (Wank, 1995), where state ownership refers to cases in which 
government is one of the shareholders of the firm (Wang et al., 2012). These two concepts are not always correlated, i.e. a state owned firm may be affiliated to a lower government level, whereas a private firm may be affiliated to a higher government level (Du \& Girma, 2010; Wang et al., 2012) ${ }^{1}$. The literature has established that, in China, whereas some firms are affiliated to central government (e.g., state or provincial-level), others are affiliated to a lower level (e.g., city- or county-level) (Wang et al., 2012). We argue that the level of government affiliation affects the ability of groups to create and appropriate value from innovation. Government in emerging economies can award major contracts and control regulatory and licensing procedures. Affiliation to higher levels of government gives groups not only higher legitimacy, status and protection, but also privileged access to critical information and opportunities to obtain government contracts and approval for new products (Yiu, Lau \& Bruton, 2007). In addition, affiliation to higher governmental levels may help the firm internationalize (Wang et al., 2012) and acquire new technologies, managerial expertise and scientific talent from abroad. This may not be available for groups affiliated at lower level of government.

Governments at higher levels can also assist groups to develop assets that increase value appropriation from innovation. Such assets are particularly important in weak IPR regimes because inexperienced groups in these emerging markets are often unable to use complexity to protect their innovations from imitation. For example, government at a higher level may allow groups to use specialized information required for developing and commercializing a new product (Wu, 2011). Since institutional influences do not develop in a vacuum, groups associated with higher government levels may also influence institutions in their favor to assist their innovation.

\footnotetext{
${ }^{1}$ Our data show that the correlation between the two constructs is 0.47 (see Table 4 in Section 4).
} 
Furthermore, different government levels have different objectives (Bai, Lu, \& Tao, 2006), exert different institutional pressures on groups and may impact innovation differently. Governments at lower levels (e.g., at the county level) focus on increasing regional output and decreasing unemployment (Li \& Zhou, 2005). Encouraging groups to invest heavily in technology development is therefore not one of their priorities. Conversely, governments at higher levels are more concerned with creating world-class technological leaders. They therefore want to push the technological frontier and offer greater support for innovation of groups. Therefore, we propose:

Hypothesis 1. The positive effects of business groups on innovation performance will be higher for groups affiliated to a higher level of government than to a lower level of government.

Social exchange theory (Emerson, 1976) suggests that groups and government engage in social exchange to achieve mutual goals. Business groups rely on government to get access to scarce resources that are not available through market channels (Wang et al., 2012), while government achieves its policy objectives by working as an ally of groups (Ghemawat \& Khanna, 1998; Yiu et al., 2005). A higher degree of state ownership ensures that decisionmaking within state-owned groups is aligned with the strategic objectives of the state, including technological catch up and international knowledge sourcing. In return, such ties with government help the group secure legitimacy and privileged market access, obtain critical resources and reduce environmental uncertainty.

When government partly owns the firm, state owned groups receive additional support from government compared with the cases where they are affiliated to government. State-owned groups in China, for example, are often given direct government subsidies, lower taxes, easier access to credit, protected home markets against domestic and foreign competition and privileged access to domestic government procurement markets. For 
example, Chinese government's stake in the Lenovo Group has given the firm support, such as financial underwriting and privileged access to markets (Luo and Tung, 2007). Many of these groups are granted a monopoly, with private enterprises not allowed to participate.

State ownership can also help groups widen the scope of their technological base. Some organizations, particularly state owned groups, can access outputs of publicly-funded R\&D that are often unavailable to other firms. Hence, they have the opportunity to add both new and different elements to their resource base, increasing the likelihood of finding valuable and rare technological combinations. Further, state ownership can help firms attract foreign technology providers (Buckley, Wang \& Clegg, 2007), widening the technological options of all group affiliates. Such complementarities may reduce information and innovation costs, assist groups in allocating their resources more efficiently, and thereby enhance innovation performance. Compared to non-state groups, groups with high levels of state ownership are also better protected by the state in terms of IPR ( $\mathrm{Li}$, Park \& Li, 2004 1999). As discrimination may prohibit non-state groups from obtaining important complementary resources, direct government support is less likely to be positively associated with the innovation activities of non-state groups. Hence:

Hypothesis 2. The positive effects of business groups on innovation will be higher for groups with a higher level of state ownership than for groups with a lower level of state ownership.

\subsection{The role of region-specific marketization}

Market development can be defined as the degree to which a region possesses marketoriented institutions, such as capital markets and labor markets (Khanna \& Palepu, 1997; Ghemawhat \& Khanna, 1998). Sub-national regions in emerging countries, especially large countries, differ significantly in the degree of market development needed for commercial activity. While market institutions are well developed in some regions, non-market influences 
and government interventions are common in other regions. The notion that one of the key benefits of groups is that they can effectively respond to market failures implies that such benefits are likely to be less important in regions where institutions are more established (Chang et al., 2006). For example, access to internal capital markets through group-based mechanisms will be less critical when alternative sources of capital, such as venture capital, are available. This argument, however, does not necessarily suggest that market mechanisms are not important for the innovation-enhancing effects of groups. Firstly, the market development creates a well-functioning market-oriented legal system and stronger enforcement mechanisms (Kafouros et al., 2012). This, in turn, enhances the flow of factors within the group and hence the effects of groups on innovation. Moreover, because the market development creates a stronger legal system and stronger enforcement mechanisms (Kafouros et al., 2012), groups affiliates in regions with well-established market systems will be better protected from the 'tunneling' effect which, through transfer of assets, supports the innovation of large affiliates but not that of smaller affiliates (Seru, 2007).

Secondly, groups in regions with well-developed markets are likely to adopt a marketdriven strategy and capitalize on the advantages of markets when it comes to coordinating factors for innovation. Governments in these regions focus on fostering innovation networks that stimulate the recombination of ideas (Mahmood \& Rufin, 2005). Because there is greater availability of external resources that creates more opportunities for innovation (Kafouros and Forsans, 2012), market development in these regions may increase a group's innovativeness (Mahmood et al., 2012). Finally, the development of market institutions stimulates competition, which in turn increases the incentives for innovation (Mahmood et al., 2012). Hence, there is a complementary effect between groups and market development in emerging economies. 
Hypothesis 3: The positive effects of business groups on innovation performance will be higher in sub-national regions with higher levels of marketization than in sub-national regions with lower levels of marketization. Figure 1 illustrates the conceptual model.

(Insert Figure 1 here)

\section{Data and methodology}

\subsection{Sample and data}

The analysis relies on a firm-level panel dataset of the Chinese manufacturing industry for the period of 2005-2007. Chinese firms are a particularly interesting group due to the idiosyncratic manner in which they are affiliated to government and the variations in institutions across regions (Wang et al., 2012). The paper uses data from the Annual Census of Chinese Industrial Firms compiled by the National Bureau of Statistics of China (NBS) for the period of 2005-2007. The Census provides detailed firm-level financial and operational information for all firms with an annual turnover of over five million Renminbi (around $\$ 680,000)$, including groups. It adopts the definition of business groups provided by the State Administration for Industry and Commerce of China (SAIC): a group consists of legally independent entities that are partly or wholly owned by a parent firm and registered as affiliated firms of that parent firm; its core company should have the register capital of over 50 million yuan (around US\$ 6.8 million), at least 5 affiliated companies, and the total register capital of the core and other affiliated companies should be over 100 million yuan (around US\$13.6 million). The Census is one of the most comprehensive datasets ever compiled by the Chinese statistical office, accounting for about 90 per cent of total output in most industries ${ }^{2}$. It has also maintained consistency in data collection across time, industries and regions (Zhou \& $\mathrm{Li}, 2008$ ). The quality of the data has been improved by undertaking extensive checks for coding errors (identifier code, industry code and geographical code),

\footnotetext{
${ }^{2}$ The database has been used by numerous studies (e.g., Girma et al., 2009; Wang et al., 2012; Yi et al., 2013).
} 
missing values and possible organizational changes (e.g., mergers and acquisitions). Outliers have also been removed. This process removed 33,083 firms out of the total of 388,602 firms, leaving us a final dataset of 355,519 firms (including both state owned and non-state owned), covering 30 two-digit manufacturing sectors throughout all 31 provinces, autonomous regions and municipalities in China.

Tables 1 and 2 provide a brief description of the groups and independent firms in the sample. Table 1 shows that 2.5 percent of the sample firms were business groups, and that 10.24 percent of them engaged in innovation during the sample period. The innovation performance of Chinese firms - measured as new product sales over total sales - is low (approximately 3 percent), supporting the view that Chinese firms are not as innovative as their western counterparts (Yi, Wang, \& Kafouros, 2013). Table 2 shows that innovation performance is higher for groups than for independent firms. This observation is in line with the theoretical discussion in Section 2 and previous findings (e.g., Amsden \& Hikino, 1994). The data also suggest that this performance discrepancy can be attributed to differences in capital intensity and R\&D intensity. Prior research emphasizes the role of government in the formation and development of groups in emerging markets (Yiu et al., 2005). This view is supported by the data that indicate that the levels of state ownership and government affiliation are higher in groups than in independent firms. This may explain why groups have higher innovation performance than independent firms.

(Insert Table 1 here)

(Insert Table 2 here)

\subsection{Measures}

Dependent and independent variables. The dependent variable is innovation performance. Following numerous studies (e.g., Liu \& Buck, 2007; Wang \& Kafouros, 2009; Yi et al., 2013), this paper measures innovation performance using the share of new product sales over 
total sales. This operationalization offers several advantages over other measures. First, as new product sales reflect the outcomes of innovation activities, it is commonly thought to be a good indicator of market acceptance of a new product (Atuahene-Gima \& Li, 2004). Second, this measure includes innovations that are not patented but are employed in the production process (Liu \& Buck, 2007). Although patents are good indicators of technological developments, they often do not reflect the economic value of these technologies, and not all innovations are patentable.

The key independent variable is business group. It is operationalized as a dummy which equals to 1 if the firm qualifies the definition of the SAIC for a business group (i.e. has at least 5 affiliated but independent entities) (which is discussed earlier), and equals to 0 otherwise. The paper further includes four institutional variables that may influence innovation performance. Government affiliation refers to the situation where a firm is attached to government (central or local) and the government takes a mentoring role. In China, this is a legacy originated from the era when the country adopted a central planning system in which every company has a government boss and all companies should report to their respective government agencies. This variable is constructed for each firm separately using the "government level" at which the firm is affiliated (Wang et al., 2012). This research assigns values of 5, 4, 3, 2, and 1 for central government, provincial government, prefectural and city government, county government, and others including the situations where the firm is not affiliated to any government. State ownership is measured by the share of state-owned assets in total assets (Wang, Hong, Kafouros, \& Boateng, 2012). We operationalize marketization adopting a measure developed by Fan, Wang, \& Zhu (2010) for 2005-2007. ${ }^{3}$ This is a comprehensive composite index that evaluates the development of market-based mechanisms in each of China's regions. It covers five key areas including the role of market

\footnotetext{
${ }^{3}$ The values of the index calculated by Fan et al. (2010) for 2005-2007 range from 2.64 to 11.71 among China's Regions. This measure has been used in several other studies (e.g., Du, Lu \& Tao, 2008).
} 
relative to government, the development of the private sector, the development of commodity and factor markets, and the development of free market institutions by a total of twenty-six indicators. A higher score indicates a stronger marketization regime.

Control variables. First, previous studies suggest that firm size is positively associated with innovation performance (e.g., Yi et al., 2013). This paper controls for firm size using the natural logarithm of total number of employees (Yi et al., 2013). Second, a firm's age can increase innovation performance by facilitating the accumulation of knowledge and experience. The paper controls for firm age using a measure of the number of years since the firm was founded (Wang et al., 2012). Third, foreign ownership may stimulate innovation due to knowledge spillovers (Wang \& Kafouros, 2009). Foreign ownership is measured using the ratio of assets owned by foreign investors to the total assets in a firm (Yi et al., 2013). Similarly, private ownership provides tighter monitoring and more effective managerial incentives than public ownership for innovation (Vickers \& Yarrow, 1988). Private ownership is measured by the ratio of assets owned by private investors to the total assets in a firm. Fourth, export-oriented firms may react to high competition in the export markets by intensively engaging in innovation. This paper controls for export intensity by using the share of export sales to total sales (Wang et al., 2012). Fifth, as innovation performance depends on R\&D inputs, $R \& D$ intensity is included, measured as total $R \& D$ expenditure divided by total sales (Zhang, Li, Hitt, \& Cui, 2007). Sixth, since profitable firms may invest more in R\&D, this effect is controlled for by incorporating a return to assets variable, measured by the ratio of total profits to total assets (Chen \& Miller, 2007). Finally, additional dummies are included to account for idiosyncrasies associated with industry, region and time variations. Table 3 summarizes the variables and their expected effects on innovation performance. Table 4 presents the mean, standard variation and correlation matrix for the key variables. All correlations among the independent variables are fairly low. The variance inflation factor 
(VIF) ranges from 1.01 to 1.89 and the average value is well below the acceptable level of 10 (Neter, Wasserman, \& Kutner, 1985), indicating that multicollinearity does not influence the estimates.

\section{(Insert Tables 3 and 4 here)}

\subsection{Model specification and estimation}

We test the hypotheses by using the following regression specification:

$\mathrm{Y}_{\mathrm{it}}=\mathrm{B}_{\mathrm{it}-1} \alpha+\mathrm{M}_{\mathrm{it}-1} \beta+\left(\mathrm{B}_{\mathrm{it}-1} \times \mathrm{M}_{\mathrm{it}-1}\right) \gamma+\mathrm{Z}_{\mathrm{it}-1} \delta+\lambda_{\mathrm{j}}+\lambda_{\mathrm{k}}+\lambda_{\mathrm{t}}+\varepsilon_{\mathrm{it}}$

where $Y_{i t}$ is innovation performance, $B_{i t-1}$ is business group, $M_{i t-1}$ denotes the four moderators - government affiliation, state ownership and region-specific marketization, $\mathrm{B}_{\mathrm{it}-1} \times \mathrm{M}_{\mathrm{it}-1}$ are the interaction terms between business group and each of the three moderators, $Z_{\mathrm{it}-1}$ are control variables, $\lambda_{\mathrm{j}}, \lambda_{\mathrm{k}}$ and $\lambda_{\mathrm{t}}$ are industry, region and time fixed effects respectively, and $\varepsilon_{\mathrm{it}}$ is the error term. While the coefficient of $\mathrm{B}_{\mathrm{it}-1}$ explains the effect of groups on innovation performance, we are more interested in the coefficients of the three interaction terms that are used to test the three hypotheses. We used pooled OLS to estimate equation (1), while controlling for industry, region and time effects.

Since unobserved firm-specific heterogeneity may affect the relationship between groups and innovation performance, we also include a firm-specific effect $\lambda_{\mathrm{i}}$ to account for this effect:

$\mathrm{Y}_{\mathrm{it}}=\mathrm{B}_{\mathrm{it}-1} \alpha+\mathrm{M}_{\mathrm{it}-1} \beta+\left(\mathrm{B}_{\mathrm{it}-1} \times \mathrm{M}_{\mathrm{it}-1}\right) \gamma+\mathrm{Z}_{\mathrm{it}-1} \delta+\lambda_{\mathrm{i}}+\lambda_{\mathrm{j}}+\lambda_{\mathrm{k}}+\lambda_{\mathrm{t}}+\varepsilon_{\mathrm{it}}$

Reverse causality problems associated with the possibility that innovation performance may impact some firm characteristics, causing estimation biases. We follow previous studies (Aitken \& Chen \& Miller, 2007; Wang, et al., 2012) and lag all independent variables by one 
year to control for possible endogeneity. ${ }^{4}$ This treatment makes endogenous variables predetermined and less likely to be correlated with the error term. The adoption of lags also accounts for the fact that these effects may take some time to materialize. Furthermore, even though multicollinearity appears not to be a concern in this study, we followed the usual practice (Aiken \& West, 1991) and mean-centered variables in the interaction terms when we estimated the models. This helps to avoid problems of multicollinearity and increases interpretability of interactions (Aiken \& West, 1991). To deal with the possible threat of heteroskedasticity, we estimated the model using Huber-White's robust standard error (White, 1980). Finally, we use hierarchical moderated regression analyses (Fang \& Zou, 2009; Wang et al., 2012; Yi et al., 2013) when we estimate the above models. Hierarchical multiple regressions allow us to determine the order that variables are entered into the regression equation in order to test the effects of certain predictors independent of the influence of others.

\section{Results}

Table 5 presents the results from the estimation of equation (1). Model 1 serves as the baseline model as it includes the predictor variable (Business group) and control variables only. The results confirm that being a business group is positively associated with innovation performance (Amsden \& Hikino, 1994). Institutional variables are added in Models 2 and 3. ${ }^{5}$ All these variables are highly statistically significant, highlighting the role of institutional factors in shaping EMEs' innovation performance. Models 4-6 present the results for the hypotheses pertaining to the contingency approach $(\mathrm{H} 1-\mathrm{H} 3)$. Following the usual practice in

\footnotetext{
${ }^{4}$ Because the sample spans three years only and the study uses panel data, it is almost unlikely to use lags of two or three years.

${ }^{5}$ As the correlation between state ownership and government affiliation is relatively high $(0.46)$, the two variables were entered in two separate regressions.
} 
moderated regression analysis (e.g., Wang et al., 2012), this paper enters two-way interactions in these models successively. Hypothesis 1 suggests that the effect of groups on innovation is reinforced by the level of government affiliation. The interaction term in Model 4 is significant, supporting Hypothesis 1. This suggests that the effects of groups are particularly pronounced when the level of government affiliation is high. By contrast, the interaction term in Model 5 is statistically insignificant, lending no support to Hypothesis 2. This finding suggests that the positive and negative effects of state ownership balance out in the data. Finally, as the coefficient of the interaction term in Model 6 is positive and significant, Hypothesis 3 is corroborated. It should be noted that these significant results are partly attributed to the use of a large sample that increases the significance of the estimates by allowing us to estimate the parameters with high precision and reduce the effect of multicollinearity on the estimates (Wooldridge, 2010). However, since statistical significance does not equal economic significance, very small coefficients may have little economic impact. Therefore, to explain better the moderating effects of government involvement, we have graphically presented these relationships in Figure 2.

(Insert Table 5 here)

(Insert Figure 2 here)

Robustness checks. To control for the estimation bias associated with unobserved firm-level heterogeneity, this study incorporated several variables that account for firm characteristics, and adopted a lag structure for independent variables. Nevertheless, to further check the robustness of the results, the paper also used panel data methods to control for such effects. To do this, it was necessary to choose between fixed and random effects models. The choice between the two depends on whether the unobserved individual effects correlate with the observed explanatory variables in the model. The random effects model is preferred to the fixed effects model if the correlation between the unobserved effects and the regressors is 
low. Otherwise, the fixed-effects model is more appropriate. Although the Hausman test can be used to make a choice between the two methods, this study employs the random effects model rather than the fixed effects model for a number of reasons. First, our sample is drawn from a large population, accounting for about $90 \%$ of total output in most industries, which may make it more appropriate to treat firm specific effects as randomly distributed over time for each individual firm (Nieto \& Rodriguez, 2011). Second, because the business group variable is constructed as a dummy, the use of fixed-effects regression will remove the effect of the business group on innovation. Finally, fixed-effects model typically produces biased estimates when the time span is relatively short (Nieto \& Rodriguez, 2011). Since our sample span three years only, the fixed effects model is not appropriate. Table $5 \mathrm{~A}$ presents the results of estimation of equation (2) with random-effects method. The key results remained qualitatively the same.

(Insert Table 5A here)

\section{Discussion}

Although extant research suggests that groups play an instrumental role in EMEs' innovation, it implicitly assumes that the impact of groups is similar regardless of the types and levels of government involvement in the group. We challenge this assumption, demonstrating that the innovation-enhancing effects of groups are contingent upon the level of government affiliation and state ownership. Furthermore, although the literature has established that groups are better able to respond to market failures (Khanna \& Palepu, 1997), it remains unclear how the development of market mechanisms shapes the way in which groups innovate. The current study underscores the important role of these institutional forces in unlocking EMEs' potential for innovation. It further shows that groups are not equally beneficial for all EMEs, but depend on the types of government involvement and the market 
development of the region in which the group operates. This analysis has a number of implications.

First, although several studies recognize that governments are behind the rise of groups in emerging markets (e.g., Mahmood \& Rufin, 2005), the role of governments in shaping the effects of group affiliation on innovation remains underexplored. The study demonstrates how government influences the ability of emerging market groups to innovate and extends the literature on the relationship between government and groups in emerging markets by showing that government affects the relationship between group affiliation and innovation performance. Furthermore, the analysis also provides a new explanation for the sources of competitive advantages that enable EMEs to innovate and compete globally even though they often do not possess internal innovative capabilities and operate in environments that, according to theory, do not stimulate innovation.

Second, unlike studies that treat government as a unidimensional construct, this paper proposes two distinct firm-level dimensions of government involvement; namely, the degree of state ownership in a given firm, and the level at which the firm is affiliated to government. The empirical findings show that government affiliation has a positive moderating effect on the relationship between group affiliation and innovation. By contrast, although state ownership has an independent effect on innovation, it does not reinforce the effect of group affiliation on innovation. This finding reflects the fact that market-based economic reforms in China have gradually reduced government favoritism toward state-owned groups, limiting their access to critical resources (Delios, Wu, \& Zhou, 2006). In such circumstances, the role of groups in filling ownership voids becomes less important. Nevertheless, the contrasting effects of state ownership and government affiliation highlight the importance of differentiating between different types of government involvement in EMEs. By explicitly differentiating different types and levels of government ownership and affiliation, our 
approach deepens understanding of the complex mechanisms through which government involvement influences the innovation of EMEs. The study thus advances the literature on the role of government in EMEs' innovation by explaining not only whether government matters but also how and which levels of government matter for innovation.

Third, the business group literature often assumes that there is institutional homogeneity within a given nation. In contrast, this study advances the premise that institutional parameters are specific to each sub-national region and that such location-specific variations influence the relationship between groups and innovation. The findings show that this relationship is stronger in regions with a higher degree of marketization than in regions with a lower degree of marketization. This suggests that the ability of firms to use groups to enhance innovation is conditioned by location-specific institutional idiosyncrasies (Chang et al., 2006). This study suggests that both complementary and substitutable effects exist between groups and institutions, and further demonstrates that the examination of institutions at country-level without capturing intra-national diversity may mask their role in shaping innovation performance. Overall, the findings of the study help to explain why and how, in emerging markets featuring weak institutions, some groups are more innovative than others.

Apart from the implications for academic research, the findings offer important guidelines to business group managers by showing how they can take advantage of the institutional environment in which they operate. Establishing links with higher governmental levels, and locating the business group's units in regions with a high degree of marketization, can prove an effective means to enhance innovation performance. As this view focuses on external relationships and power (Capron \& Chatain, 2008), it differs from traditional prescriptions that emphasize internal efficiency and R\&D capabilities. Nevertheless, this does not imply that managers should always rely only on advantages derived from their institutional environment and pay less attention to the development of firm-specific 
resources. Reliance on political institutions and government may reduce the firm's motivation to become technologically competitive through developing internal technological capabilities.

Nevertheless, this study has several limitations. First, it focuses on the interplay between groups and several favorable institutional factors. However, it places less emphasis on a number of institutional setups that may hinder the role of groups in emerging markets. Future research should consider such disadvantages and identify the conditions under which the negative effects of institutional factors may outweigh the associated benefits. Second, as the empirical results rely on Chinese firms, it may not be possible to generalize the findings. For instance, Chinese business groups may exhibit a particular set of characteristics because of the dominance of large SOEs and the unique role of government. As institutions and regulations vary significantly across emerging markets, future studies based on other emerging countries will identify such differences. Third, both groups and the institutional environment in emerging markets evolve rapidly. The role of both groups and government institutions in emerging markets may fade away as they converge with those in Western economies. Although the time length of the data does not allow the research to examine the co-evolution of groups and governments and its consequences for innovation, this is a promising research topic that warrants further investigation. 


\section{References}

Aiken, L., \& West, S. (1991). Multiple regression: Testing and interpreting interactions. Newbury Park, CA: Sage Publications.

Amsden, A., \& Hikino, T. (1994). Project execution capability, organizational know-how and conglomerate corporate growth in late industrialization. Industrial Corporate Change, 3 , 111-147.

Atuahene-Gima, K., \& Li, H. (2004). Strategic decision comprehensiveness and new product outcomes in new technology ventures. Academy of Management Journal, 47, 583-597.

Bai, C., Lu, J., \& Tao, Z. (2006). The multitask theory of state enterprise reform: Empirical evidence from China. American Economic Review, 96, 353-357.

Barney, J. B. (1991). Firm resources and sustained competitive advantage. Journal of Management, 17, 99-120.

Boddewyn, J. J., \& Brewer, T. (1994). International-business political behavior: New theoretical directions. Academy of Management Review, 19, 119 -144.

Buckley, P., Clegg, J., \& Wang, C. (2007). The impact of foreign ownership, local ownership and industry characteristics on spillovers from foreign direct investment in China. International Business Review, 16, 142-158.

Capron, L., \& Chatain, O. (2008). Competitors' resource-oriented strategies: Acting on competitors' resources through interventions in factor markets and political markets. Academy of Management Review, 33, 97-121.

Chang, S. J., Chung, C.N., \& Mahmood, I. P. (2006). When and how does business group affiliation promote firm innovation? A tale of two emerging economies. Organization Science, 17, 637-656. 
Chang, S., \& Hong, J. (2000). Economic performance of group-affiliated companies in Korea: Intra-group resource sharing and internal business transactions. Academy of Management Journal, 43, 429-448.

Chen, W.R., \& Miller, K. D. (2007). Situational and institutional determinants of firms' R\&D search intensity. Strategic Management Journal, 28, 369-381.

Delios, A., Wu, Z., \& Zhou, N. (2006). A new perspective on ownership identities in China's listed companies. Management and Organization Review, 2, 319-343.

DiMaggio, P. J., \& Powell, W. W. (1983). The iron cage revisited: Institutional isomorphism and collective rationality in organization fields. American Sociological Review, 48(2): $147-160$.

Du, J., \& Girma, S. (2010). Red capitalists: Political connections and firm performance in China. Kyklos, 63, 530-545.

Du, J., Lu, Y. \& Tao, Z. (2008). Economic institutions and FDI location choice: Evidence from US multinationals in China. Journal of Comparative Economics, 36, 412-429.

Emerson, R. M. (1976). Social exchange theory. Annual Review of Sociology, 2, 335-362.

Fan, G., Wang, X., \& Zhu, H. (2010). NERI index of marketization of China's provinces 2009 report. Beijing: Economic Science Press.

Fang, E. \& Zou, S. (2009). Antecedents and consequences of marketing dynamic capabilities in international joint ventures. Journal of International Business Studies, 40, 742-61.

George, R., \& Kabir, R. (2012). Heterogeneity in business groups and the corporate diversification-firm performance relationship. Journal of Business Research, 65, 412420.

Ghemawhat, P., \& Khanna, T. (1998). The nature of diversified business groups. Journal of Industrial Economics, 46, 35-61. 
Granovetter, M. (1995). Coarse revisited: Business groups in the modern economy. Industrial Corporate Change, 4, 93-140.

Kafouros, M. I., Buckley, P. J., \& Clegg, J. (2012). The effects of global knowledge reservoirs on the productivity of multinational enterprises: The role of international depth and breadth. Research Policy, 41(5), 848-861.

Kafouros, M. I., \& Forsans, N. (2012). The role of open innovation in emerging economies: Do companies profit from the scientific knowledge of others?. Journal of World Business, 47(3), 362-370.

Khanna, T., \& Palepu, K. (1997). Why focused strategies may be wrong for emerging markets. Harvard Business Review, 75, 41-51.

Khanna, T., \& Yafeh, Y. (2007). Business groups in emerging markets: paragons or parasites. Journal of Economic Literature, XLV, 331-372.

La Porta, R., Lopez-de-Silanes, F., Shleifer, A., \& Vishny, R. (2000). Investor protection and corporate governance. Journal of Financial Economics, 58, 3-27.

Li, S., Park, S. H., \& Li, S. (2004). The great leap forward: the transition from relation-based governance to rule-based governance. Organizational Dynamics, 33, 63-78.

Li, H., \& Zhou, L. (2005). Political turnover and economic performance: The incentive role of personnel control in China. Journal of Public Economics, 89, 1743-1762.

Lin, N. (2001). Building a network theory of social capital. Connections, 22, 28-51.

Liu, X., \& Buck, T. (2007). Innovation performance and channels for international technology spillovers: Evidence from Chinese high-tech industries. Research Policy, 36, 355-366.

Luo, Y., \& Tung, R. (2007). International expansion of emerging market enterprises: A springboard perspective. Journal of International Business Studies, 38, 481-498. 
Mahmood, I. P., Chung, C. N., \& Mitchell, W. (2012). The evolving impact of combinatorial opportunities and exhaustion on innovation by business groups as market development increases: The case of Taiwan. Management Science, doi: 10.1287/mnsc.1120.1605.

Mahmood, I. P., \& Mitchell, W. (2004). Two faces: Effects of business groups on innovation in emerging economies. Management Science, 50, 1348-1365.

Mahmood, I. P. \& Rufin, C. (2005). Government's dilemma: The institutional framework for imitation and innovation. Academy of Management Review, 30, 338-360.

Mahmood, I. P., \& Singh, J. (2003). Technological dynamism in Asia. Research Policy, 32, 1031-1054.

Neter, J., Wasserman, W., \& Kutner, M. H. (1985). Applied linear statistical models. Homewood, IL: Irwin.

Nieto, M. J., \& Rodriguez, A. (2011). Offshoring of R\&D: Looking abroad to improve innovation performance. Journal of International Business Studies, 42, 345-361.

Oliver, C. (1997). Sustainable competitive advantage: Combining institutional and resourcebased views. Strategic Management Journal, 18, 697-713.

Peng, M. W., \& Luo, Y. (2000). Managerial ties and firm performance in a transition economy: The nature of a micro-macro link. Academy of Management Journal, 43, 486501.

Ricart. J. E., Enright, M. J., Ghemawat, P., Hart, S. L., \& Khanna, T. (2004). New frontier in international strategy. Journal of International Business Studies, 35, 175-200.

Scott, W. R. (1995). Institutions and organizations. Thousand Oaks, CA: Sage.

Seru, A. (2007). Do conglomerates stifle innovation? The University of Chicago working paper.

Vickers, J. \& Yarrow, G. (1988). Privatization: An Economic Analysis. Cambridge, MA: MIT Press. 
Wan, W. P., \& Hoskisson, R. (2003). Home country environments, corporate diversification strategies, and firm performance. Academy of Management Journal, 46, 27-45.

Wang, C., Hong, J., Kafouros, M., \& Boateng, A. (2012). What Drives the Internationalization of Chinese Firms? Testing the Explanatory Power of Three Theoretical Frameworks. International Business Review, 21, 426-438.

Wang, C., Hong, J., Kafouros, M., \& Wright, M. (2012). Exploring the role of government involvement in outward direct investment from emerging economies. Journal of International Business Studies, 43, 655-676.

Wang, C., \& Kafouros, M. (2009). What factors determine innovation performance in emerging economies? Evidence from China. International Business Review, 18, 606616.

Wank, D. 1995. Private business, bureaucracy, and political alliance in a Chinese city. Australian Journal of Chinese Affairs, 33(1): 55-71.

White, H. (1980). A heteroscedasticity consistent covariance matrix estimator and a direct test for heteroscedasticity. Econometrica, 48, 817-838.

Wooldridge, J. M. (2012). Introductory econometrics: A modern approach. 5th edition. Mason, $\mathrm{OH}, \mathrm{US}$ : Southern-Western Cengage Learning.

$\mathrm{Wu}$, J. (2011). The asymmetric roles of business ties and political ties in product innovation. Journal of Business Research, 64, 1151-1156.

Yi, J., Wang, C., \& Kafouros, M. (2013). The effects of innovative capabilities on exporting: Do institutional forces matter? International Business Review, 22, 392-406.

Yiu, D., Bruton, G., \& Lu, Y. (2005). Understanding business group performance in an emerging economy: Acquiring resources and capabilities in order to prosper. Journal of Management Studies, 42, 183-296. 
Yiu, D. W., Lau, C. M., \& Bruton, G. D. (2007). International venturing by emerging economy firms: The effects of firm capabilities, home country networks, and corporate entrepreneurship. Journal of International Business Studies, 38, 519-540.

Zander, U. \& Kogut, B. (1995). Knowledge and the speed of the transfer and imitation of organizational capabilities: An empirical test. Organization Science, 6, 76-92.

Zhang, Y., Li, H., Hitt, M. A., \& Cui, G. (2007). R\&D intensity and international joint venture performance in an emerging market: moderating effects of market focus and ownership structure. Journal of International Business Studies, 38, 944-960.

Zhou, C., \& Li, J. (2008). Product innovation in emerging market-based international joint ventures: An organizational ecology perspective. Journal of International Business Studies, 39, 1114-1132. 
Figures and Tables

Figure 1 Research model

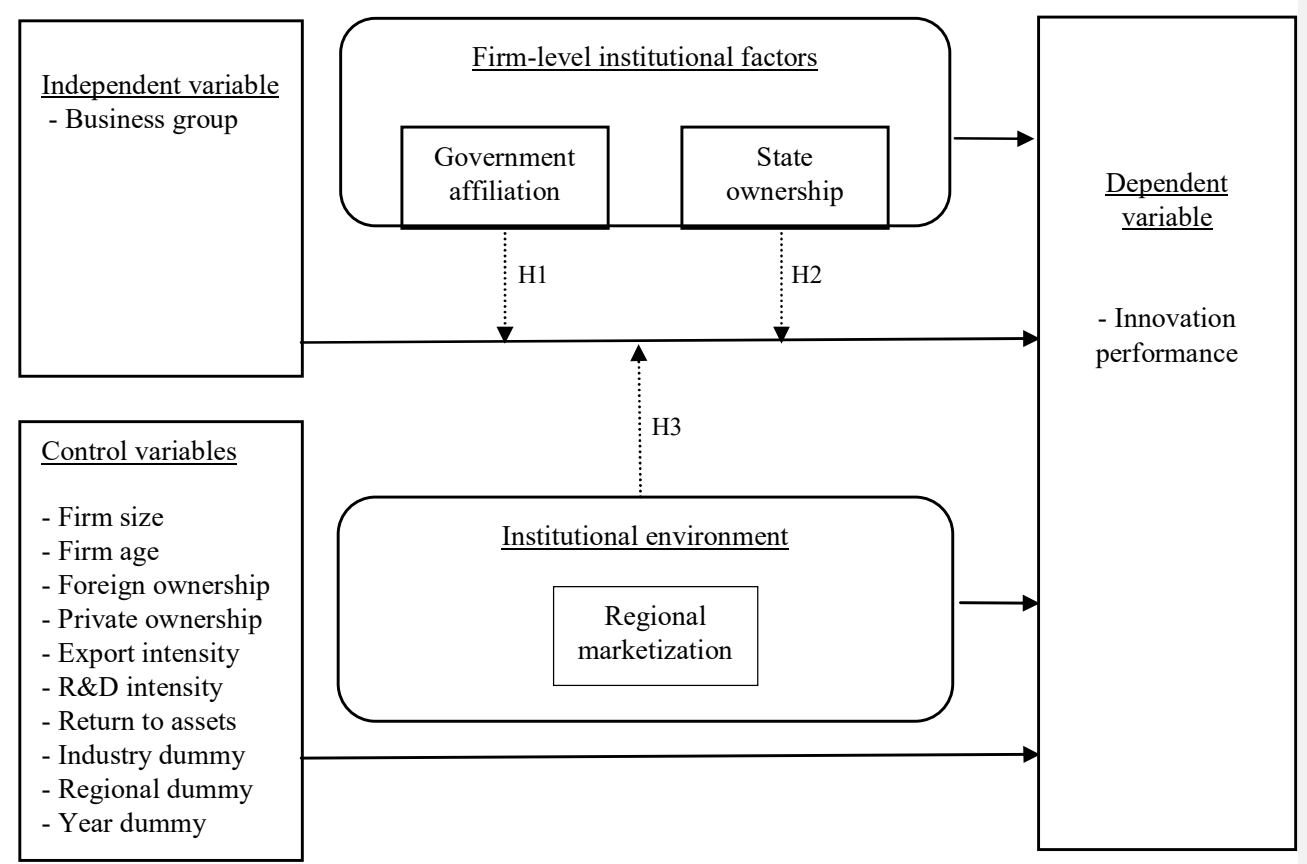

Figure 2 Moderating effects of institutional factors

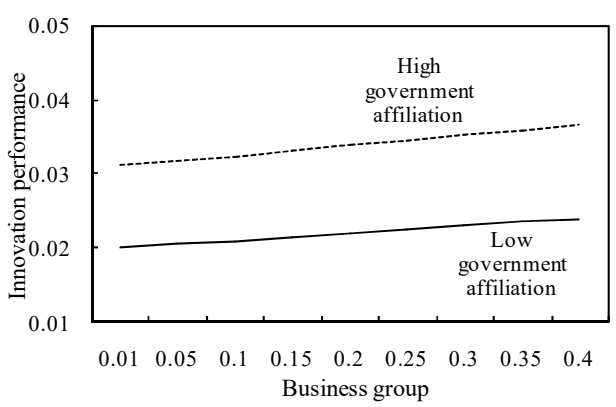

(a) Moderating role of government affiliation

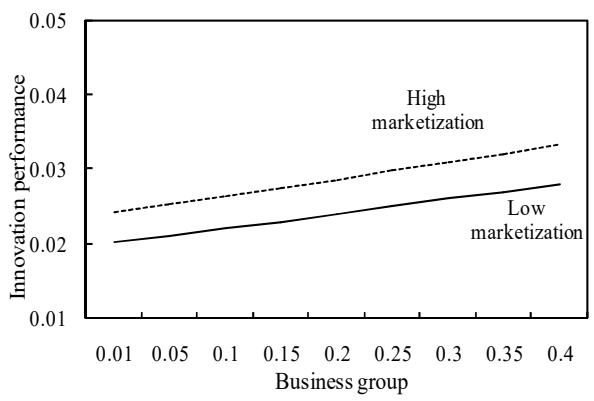

(b) Moderating role of marketization 
Table 1 Business group and innovation patterns of Chinese firms

\begin{tabular}{ccccc}
\hline Year & All firms & Business groups & Innovators & Innovation performance \\
\hline 2005 & 245,493 & $7,405(3.0 \%)$ & $24,417(9.9 \%)$ & 0.030 \\
2006 & 272,671 & $7,120(2.6 \%)$ & $28,149(10.3 \%)$ & 0.032 \\
2007 & 300,545 & $6,220(2.1 \%)$ & $31,295(10.4 \%)$ & 0.032 \\
Average & 272,903 & $6,915(2.5 \%)$ & $27,954(10.2 \%)$ & 0.031
\end{tabular}

Note: Innovators are firms that report positive R\&D expenditures. Innovation performance is the ratio of new product sales over total sales. Percentage shares of total sample are reported in parentheses.
Comment [P1]: lingtao: please get the position of 'Note' right. 
Table 2 Differences between business groups and independent firms

\begin{tabular}{|c|c|c|c|c|c|c|c|c|c|c|c|c|}
\hline & \multirow{2}{*}{ Variables } & \multicolumn{5}{|c|}{ Independent firms } & \multicolumn{5}{|c|}{ Business groups } & \multirow{2}{*}{ Difference } \\
\hline & & Mean & Median & S.d. & Min & $\operatorname{Max}$ & Mean & Median & S.d. & Min & Max & \\
\hline \multirow[t]{5}{*}{2005} & Innovation performance & 0.029 & 0 & 0.134 & 0 & 1 & 0.065 & 0 & 0.178 & 0 & 1 & $0.030^{* * *}$ \\
\hline & Capital intensity & 90 & 41 & 247 & 0.002 & 30,119 & 112 & 57 & 210 & 0.004 & 7,067 & $0.267 * * *$ \\
\hline & R\&D intensity & 0.001 & 0 & 0.013 & 0 & 0.918 & 0.004 & 0 & 0.019 & 0 & 0.783 & $0.002 * * *$ \\
\hline & State ownership & 0.043 & 0 & 0.192 & 0 & 1 & 0.164 & 0 & 0.192 & 0 & 1 & $0.105 * * *$ \\
\hline & Government affiliation & 1.277 & 1 & 0.742 & 1 & 5 & 1.919 & 1 & 0.742 & 1 & 5 & $0.266 * * *$ \\
\hline \multirow[t]{5}{*}{2006} & Innovation performance & 0.031 & 0 & 0.138 & 0 & 1 & 0.077 & 0 & 0.196 & 0 & 1 & $0.036 * * *$ \\
\hline & Capital intensity & 97 & 45 & 329 & 0.001 & 84,198 & 123 & 60 & 383 & 0.006 & 24,825 & $0.259 * * *$ \\
\hline & R\&D intensity & 0.002 & 0 & 0.014 & 0 & 0.963 & 0.004 & 0 & 0.022 & 0 & 0.677 & $0.002 * * *$ \\
\hline & State ownership & 0.033 & 0 & 0.169 & 0 & 1 & 0.141 & 0 & 0.330 & 0 & 1 & $0.096 * * *$ \\
\hline & Government affiliation & 1.244 & 1 & 0.698 & 1 & 5 & 1.824 & 1 & 1.261 & 1 & 5 & $0.245 * * *$ \\
\hline \multirow[t]{5}{*}{2007} & Innovation performance & 0.031 & 0 & 0.139 & 0 & 1 & 0.075 & 0 & 0.198 & 0 & 1 & $0.027 * * *$ \\
\hline & Capital intensity & 102 & 48 & 480 & 0.001 & 209,521 & 103 & 55 & 212 & 0.012 & 9,990 & $0.138 * * *$ \\
\hline & R\&D intensity & 0.002 & 0 & 0.014 & 0 & 0.991 & 0.005 & 0 & 0.022 & 0 & 0.859 & $0.002 * * *$ \\
\hline & State ownership & 0.020 & 0 & 0.132 & 0 & 1 & 0.091 & 0 & 0.274 & 0 & 1 & $0.067 * * *$ \\
\hline & Government affiliation & 1.209 & 1 & 0.638 & 1 & 5 & 1.632 & 1 & 1.138 & 1 & 5 & $0.190 * * *$ \\
\hline \multirow[t]{5}{*}{ Overall } & Innovation performance & 0.030 & 0 & 0.137 & 0 & 1 & 0.072 & 0 & 0.190 & 0 & 1 & $0.031 * * *$ \\
\hline & Capital intensity & 97 & 45 & 373 & 0.001 & 209,521 & 113 & 57 & 282 & 0.004 & 24,825 & $0.214 * * *$ \\
\hline & R\&D intensity & 0.002 & 0 & 0.014 & 0 & 0.991 & 0.004 & 0 & 0.021 & 0 & 0.859 & $0.002 * * *$ \\
\hline & State ownership & 0.031 & 0 & 0.164 & 0 & 1 & 0.134 & 0 & 0.324 & 0 & 1 & $0.093 * * *$ \\
\hline & Government affiliation & 1.241 & 1 & 0.691 & 1 & 5 & 1.800 & 1 & 1.240 & 1 & 5 & $0.238 * * *$ \\
\hline
\end{tabular}

Note: Difference is the coefficient on business group in a regression of the log of the firm characteristics on business group, 2-digit industry dummies and regional dummies. *** Significant at the $1 \%$ level. 
Table 3 Definition of variables

\begin{tabular}{|c|c|c|}
\hline & Definition & Expected \\
\hline \multicolumn{3}{|l|}{ Dependent variable } \\
\hline \multicolumn{3}{|l|}{ Independent variable } \\
\hline \multicolumn{3}{|c|}{ ( } \\
\hline Government affiliation & $\begin{array}{l}\text { A value of } 5 \text { is assigned for central government affiliation, } 4 \text { for provincial, } 3 \text { for city, } 2 \\
\text { for county, } 1 \text { for others }\end{array}$ & + \\
\hline State ownership & Ratio of state-owned assets to total assets & + \\
\hline Marketization & Region-specific marketization index by Fan et al. (2010) & $+/-$ \\
\hline \multicolumn{3}{|l|}{ Control variables } \\
\hline Firm size & Log (number of employees) & + \\
\hline Firm age & Number of years since establishment & + \\
\hline Foreign ownership & Foreign capital share & + \\
\hline Private ownership & Private capital share & + \\
\hline Export intensity & Ratio of export sales to total sales & + \\
\hline R\&D intensity & Ratio of R\&D expenditures to total sales in a lagged period & + \\
\hline Return to assets & Ratio of total profits to total assets in a lagged period & + \\
\hline Industry dummy & Dummy, equals to 1 if affiliated at the corresponding two-digit industry & \\
\hline Region dummy & Dummy, equals to 1 if located at the corresponding province-level region & \\
\hline Year dummy & Dummy, equals to 1 if associated with the corresponding year & \\
\hline
\end{tabular}


Table 4 Descriptive statistics and correlation matrix of variables

\begin{tabular}{|c|c|c|c|c|c|c|c|c|c|c|c|c|c|c|}
\hline & \multirow{2}{*}{ Mean } & \multirow{2}{*}{$\begin{array}{l}\text { Standard } \\
\text { deviation }\end{array}$} & & & & & & & & & & & & \\
\hline & & & 1 & 2 & 3 & 4 & 5 & 6 & 7 & 8 & 9 & 10 & 11 & 12 \\
\hline 1 Innovation performance & 0.031 & 0.139 & 1.00 & & & & & & & & & & & \\
\hline 2 Business group & 0.025 & 0.157 & 0.05 & 1.00 & & & & & & & & & & \\
\hline 3 Government affiliation & 1.255 & 0.715 & 0.09 & 0.12 & 1.00 & & & & & & & & & \\
\hline 4 State ownership & 0.034 & 0.171 & 0.03 & 0.10 & 0.47 & 1.00 & & & & & & & & \\
\hline 5 Marketization & 9.043 & 1.728 & 0.03 & -0.02 & -0.22 & -0.16 & 1.00 & & & & & & & \\
\hline 6 Firm size & 4.641 & 1.074 & 0.08 & 0.14 & 0.16 & 0.07 & -0.04 & 1.00 & & & & & & \\
\hline 7 Firm age & 8.150 & 9.000 & 0.05 & 0.15 & 0.32 & 0.32 & -0.05 & 0.20 & 1.00 & & & & & \\
\hline 8 Foreign ownership & 0.084 & 0.261 & 0.01 & -0.02 & -0.03 & -0.05 & 0.11 & 0.12 & -0.05 & 1.00 & & & & \\
\hline 9 Private ownership & 0.750 & 0.411 & -0.00 & -0.03 & -0.16 & -0.33 & -0.09 & -0.21 & -0.17 & -0.52 & 1.00 & & & \\
\hline 10 Export intensity & 0.170 & 0.340 & 0.05 & -0.01 & -0.08 & -0.07 & 0.24 & 0.24 & -0.01 & 0.26 & -0.29 & 1.00 & & \\
\hline 11 R\&D intensity & 0.002 & 0.014 & 0.19 & 0.03 & 0.09 & 0.03 & 0.00 & 0.04 & 0.04 & 0.01 & -0.01 & -0.02 & 1.00 & \\
\hline 12 Return to assets & 0.101 & 0.436 & -0.01 & -0.02 & -0.06 & -0.04 & -0.04 & -0.02 & -0.04 & -0.02 & 0.05 & -0.03 & -0.01 & 1.00 \\
\hline
\end{tabular}

Note: All the correlation coefficients are statistically different from zero at the $1 \%$ significance level. 
Table 5 Hierarchical moderated regression of innovation performance 2005-2007

\begin{tabular}{|c|c|c|c|c|c|c|}
\hline & Model 1 & Model 2 & Model 3 & Model 4 & Model 5 & Model 6 \\
\hline \multicolumn{7}{|l|}{ Independent variable } \\
\hline Business group & $0.015 * * *$ & $0.012 * * *$ & $0.015 * * *$ & $0.010 * * *$ & $0.014 * * *$ & $0.020 * * *$ \\
\hline \multicolumn{7}{|l|}{ Moderators } \\
\hline Government affiliation & & $0.011 * * *$ & & $0.011 * * *$ & & $0.013 * * *$ \\
\hline State ownership & & & $0.014 * * *$ & & $0.014 * * *$ & \\
\hline Marketization & & $0.008 * * *$ & $0.008 * * *$ & $0.008 * * *$ & $0.008 * * *$ & $0.004 * * *$ \\
\hline \multicolumn{7}{|l|}{ Interactions } \\
\hline Business group $\times$ Government affiliation & & & & $0.004 * * *$ & & \\
\hline Business group $\times$ State ownership & & & & & 0.002 & \\
\hline Business group $\times$ Marketization & & & & & & $0.003 * * *$ \\
\hline \multicolumn{7}{|l|}{ Control variables } \\
\hline Firm size & $0.012 * * *$ & $0.011 * * *$ & $0.012 * * *$ & $0.011 * * *$ & $0.012 * * *$ & $0.009 * * *$ \\
\hline Firm age & $0.000 * * *$ & $0.000 * * *$ & $0.000 * * *$ & $0.000 * * *$ & $0.000 * * *$ & $0.000 * * *$ \\
\hline Foreign ownership & 0.001 & $0.004 * * *$ & $0.003 * * *$ & $0.004 * * *$ & $0.003 * * *$ & $0.005 * * *$ \\
\hline Private ownership & $0.009 * * *$ & $0.012 * * *$ & $0.011 * * *$ & $0.012 * * *$ & $0.011 * * *$ & $0.019 * * *$ \\
\hline Export intensity & $0.009 * * *$ & $0.011 * * *$ & $0.010 * * *$ & $0.011 * * *$ & $0.010 * * *$ & $0.013 * * *$ \\
\hline R\&D intensity & $1.623 * * *$ & $1.589 * * *$ & $1.618 * * *$ & $1.588 * * *$ & $1.618 * * *$ & $1.703 * * *$ \\
\hline Return to assets & $0.004 * * *$ & $0.006 * * *$ & $0.005 * * *$ & $0.006 * * *$ & $0.005 * * *$ & $0.001 * *$ \\
\hline Industry dummies & Yes & Yes & Yes & Yes & Yes & Yes \\
\hline Region dummies & Yes & Yes & Yes & Yes & Yes & No \\
\hline Year dummies & Yes & Yes & Yes & Yes & Yes & Yes \\
\hline Sample size & 460,176 & 460,017 & 460,017 & 460,017 & 460,017 & 460,017 \\
\hline F-statistic & $236.47 * * *$ & $236.03 * * *$ & $230.76^{* * *}$ & $232.77 * * *$ & $227.52 * * *$ & $233.93 * * *$ \\
\hline Adjusted $\mathrm{R}^{2}$ & 0.07 & 0.08 & 0.08 & 0.08 & 0.08 & 0.08 \\
\hline
\end{tabular}

Note: $* * *$ and $* * *$ are significantly different from zero at the $10 \%, 5 \%$ and $1 \%$ level respectively. 
Table 5A Random effects regression of innovation performance 2005-2007

\begin{tabular}{|c|c|c|c|c|c|c|}
\hline & Model 1 & Model 2 & Model 3 & Model 4 & Model 5 & Model 6 \\
\hline \multicolumn{7}{|l|}{ Independent variable } \\
\hline Business group & $0.014 * * *$ & $0.012 * * *$ & $0.013 * * *$ & $0.010 * * *$ & $0.013 * * *$ & $0.018 * * *$ \\
\hline \multicolumn{7}{|l|}{ Moderators } \\
\hline Government affiliation & & $0.010 * * *$ & & $0.010 * * *$ & & $0.012 * * *$ \\
\hline State ownership & & & $0.010 * * *$ & & $0.009 * * *$ & \\
\hline Marketization & & $0.011 * * *$ & $0.010 * * *$ & $0.011 * * *$ & $0.010 * * *$ & $0.004 * * *$ \\
\hline \multicolumn{7}{|l|}{ Interactions } \\
\hline Business group $\times$ Government affiliation & & & & $0.005 * * *$ & & \\
\hline Business group $\times$ State ownership & & & & & 0.006 & \\
\hline Business group $\times$ Marketization & & & & & & $0.001 * *$ \\
\hline \multicolumn{7}{|l|}{ Control variables } \\
\hline Firm size & $0.011 * * *$ & $0.011 * * *$ & $0.011 * * *$ & $0.011 * * *$ & $0.011 * * *$ & $0.009 * * *$ \\
\hline Firm age & $0.000 * * *$ & $0.000 * * *$ & $0.000 * * *$ & $0.000 * * *$ & $0.000 * * *$ & $0.000 * * *$ \\
\hline Foreign ownership & 0.001 & $0.003 * * *$ & $0.002 * *$ & $0.003 * * *$ & $0.002 * *$ & $0.003 * * *$ \\
\hline Private ownership & $0.006^{* * *}$ & $0.008 * * *$ & $0.008 * * *$ & $0.008 * * *$ & $0.008 * * *$ & $0.014 * * *$ \\
\hline Export intensity & $0.006 * * *$ & $0.007 * * *$ & $0.007 * * *$ & $0.007 * * *$ & $0.007 * * *$ & $0.008 * * *$ \\
\hline R\&D intensity & $0.910 * * *$ & $0.893 * * *$ & $0.906 * * *$ & $0.893 * * *$ & $0.906 * * *$ & $0.947 * * *$ \\
\hline Return to assets & $0.002 * *$ & $0.003 * * *$ & $0.002 * * *$ & $0.003 * * *$ & $0.002 * * *$ & $0.000 *$ \\
\hline Industry dummies & Yes & Yes & Yes & Yes & Yes & Yes \\
\hline Region dummies & Yes & Yes & Yes & Yes & Yes & No \\
\hline Year dummies & Yes & Yes & Yes & Yes & Yes & Yes \\
\hline Sample size & 460,176 & 460,017 & 460,017 & 460,017 & 460,017 & 460,017 \\
\hline Wald test of full model & $24515.73 * * *$ & $25599.41 * * *$ & $24662.87 * * *$ & $25620.83 * * *$ & $24665.01 * * *$ & $15319.61 * * *$ \\
\hline Adjusted $\mathrm{R}^{2}$ & 0.07 & 0.08 & 0.08 & 0.08 & 0.08 & 0.08 \\
\hline
\end{tabular}

at the $10 \%, 5 \%$ and $1 \%$ level respectively. 